\title{
Features of modern development and use of specially protected natural territories in the Khanty-Mansiya autonomous area
}

\author{
Olga Bogdanova ${ }^{1, *}$ \\ ${ }^{1}$ Industrial University of Tyumen, 625001, Tyumen city, Russia
}

\begin{abstract}
This article proposes to consider the features of the use of specially protected natural areas in the Khanty-Mansiysk Autonomous Okrug - Yugra. The main prospects for the use of protected areas are considered, taking into account the environmental, economic and social factors of development, an approach is proposed for the introduction of ecological tourism in the activities of specially protected natural areas. A forecast of changes in the main indicators of effective management of protected areas has been made.
\end{abstract}

\section{Introduction}

Khanty-Mansiysk Autonomous Okrug - Yugra has a rich tourist and recreational potential: specially protected natural areas, historical and cultural monuments, cultural and historical resources, the original cultural heritage of the indigenous peoples of the North and modern infrastructure.

The rich tourist and recreational, historical, cultural, ethnographic, socio-economic potential of the Autonomous Okrug and the availability of tourist infrastructure determine the role of the tourism industry in the economy of the Autonomous Okrug as one of the economic sectors, the successful development of which will have a stimulating effect on the development of such spheres of economic activity as services of collective accommodation facilities, transport, communications, trade, production of souvenirs, public catering, and will also act as a catalyst for the socio-economic development of municipalities of the Autonomous Okrug.

\section{Methodology}

Currently, there are three tourist and recreational zones in the Khanty-Mansiysk Autonomous Okrug (Table 1).

\footnotetext{
${ }^{*}$ Corresponding author: chernyheg@tyuiu.ru
} 
Table 1. Tourist and recreational zones of the Khanty-Mansi Autonomous Okrug-Yugra.

\begin{tabular}{|c|c|c|c|}
\hline Zone name & Composition & Features & $\begin{array}{c}\text { Development } \\
\text { prospects }\end{array}$ \\
\hline $\begin{array}{l}\text { Eastern } \\
\text { zone }\end{array}$ & $\begin{array}{l}\text { Surgut, Nefteyugansk, } \\
\text { Nizhnevartovsk districts, } \\
\text { cities: Surgut, } \\
\text { Nizhnevartovsk, } \\
\text { Kogalym, Langepas, } \\
\begin{array}{l}\text { Megion, Raduzhny, } \\
\text { Pokachi, Nefteyugansk } \\
\text { and Pyt-Ya }\end{array}\end{array}$ & $\begin{array}{l}\text { - industrial character - } \\
\text { monotony of landscapes - } \\
\text { developed transport } \\
\text { infrastructure - a well- } \\
\text { developed network of } \\
\text { accommodation facilities, } \\
\text { leisure and entertainment } \\
\text { facilities, catering points, } \\
\text { etc. (eastern part of } \\
\text { Nizhnevartovsk and } \\
\text { southern (left-bank) part of } \\
\text { Surgut districts) }\end{array}$ & $\begin{array}{l}\begin{array}{l}\text { Development of } \\
\text { ethnographic, cultural, } \\
\text { educational, water } \\
\text { (river) tourism, }\end{array} \\
\text { industrial tourism with } \\
\text { visiting memorable } \\
\text { places from the history } \\
\text { of the development of } \\
\text { the oil and gas } \\
\text { complex of the } \\
\text { Autonomous Okrug. }\end{array}$ \\
\hline $\begin{array}{l}\text { Western } \\
\text { zone }\end{array}$ & $\begin{array}{l}\text { Territory from the } \mathrm{Ob} \\
\text { and Irtysh rivers to the } \\
\text { Northern Urals: Khanty- } \\
\text { Mansi region (left-bank } \\
\text { part), Soviet and } \\
\text { Oktyabrsky regions (left- } \\
\text { bank part), Kondinsky } \\
\text { region, cities: Khanty- } \\
\text { Mansiysk, Urai, } \\
\text { Yugorsk, Nyagan. }\end{array}$ & $\begin{array}{l}- \text { the main transport } \\
\text { highway Khanty-Mansiysk } \\
- \text { Nyagan - Yugorsk - } \\
\text { Mezhdurechensk. } \\
- \text { favorable ecological } \\
\text { situation } \\
- \text { the largest number of } \\
\text { protected areas } \\
\text { - construction of the } \\
\text { highway Perm - Serov - } \\
\text { Khanty-Mansiysk - Surgut } \\
\text { - Nizhnevartovsk - Tomsk }\end{array}$ & $\begin{array}{l}\text { Development of } \\
\text { ecological, } \\
\text { ethnographic, event, } \\
\text { sports and cultural, } \\
\text { educational, health- } \\
\text { improving tourism }\end{array}$ \\
\hline $\begin{array}{l}\text { Northern } \\
\text { zone }\end{array}$ & $\begin{array}{l}\text { Territories of } \\
\text { Berezovsky, Beloyarsky, } \\
\text { Khanty-Mansiysk (right- } \\
\text { bank part), Oktyabrsky } \\
\text { (right-bank part) regions } \\
\text { and the city of } \\
\text { Beloyarsky }\end{array}$ & $\begin{array}{l}\text { - favorable ecological } \\
\text { situation } \\
\text { - the mountains of the } \\
\text { Subpolar Urals with the } \\
\text { highest mountain in the } \\
\text { Urals, Narodnaya } \\
\text { - attractions of the urban- } \\
\text { type settlement Berezovo }\end{array}$ & $\begin{array}{l}\text { Extreme, ecological, } \\
\text { ethnographic and } \\
\text { cultural tourism. There } \\
\text { are opportunities for } \\
\text { the development of } \\
\text { water, amateur and } \\
\text { active tourism }\end{array}$ \\
\hline
\end{tabular}

Taking into account the location of protected areas in the territory of the district, it can be concluded that the most promising territories for the development of ecological tourism are the Western and Northern zones.

The territory of the Khanty-Mansi Autonomous Okrug-Yugra is characterized by an established system of protected areas, which is in the development stage. The protected areas of the Autonomous Okrug form a huge potential for the development of ecological tourism, including the organization of ethnographic tours, ecological tours with elements of fishing, hunting, recreation, etc.

Let us consider in more detail the possibility of organizing a tourist route through the protected areas of the Khanty-Mansi Autonomous Okrug-Yugra with the aim of developing ecological tourism, involving the protected areas in investment activities, using the recreational potential of the protected areas to create conditions for the economic growth of municipalities in which they are located, as well as individual settlements organization of tourist infrastructure. The ecological operation of protected areas will ensure the receipt of revenues in the budgets of all levels.

In our opinion, the most acceptable potential protected areas for the development of ecological tourism in the Khanty-Mansi Autonomous Okrug may be: 
1. State natural complex reserve of regional significance "Untorsky" was created in order to preserve and reproduce wild animals, their habitat and serves to maintain the overall ecological balance of the Oktyabrsky district, located in the northern taiga zone in the left-bank part of the river basin. Ob.

The area of the Untorsky reserve is 81,526 hectares.

The hydrographic network of the territory under consideration belongs to the Kara Sea basin and is represented by a large number of rivers and rivers with a constant flow. The most significant rivers are the $\mathrm{Ob}$ and its tributaries. The main features of hydrography and the regime of water bodies in a given territory are determined by complex combinations of climatic features, relief, and geological structure. A characteristic feature of the territory is the wide distribution of lakes and swamps.

The boundaries of the reserve include the river system of the Ob River with flooded sores, a network of river channels, well-drained, flat-wavy terraces with spruce-birch with fir and cedar forests, which are habitats for game species of animals, waterfowl, muskrat, animal and plant species, included in the Red Data Book of the Russian Federation and the Red Data Book of the Autonomous Okrug, as well as spawning and feeding grounds for valuable fish species.

The location of the reserve is shown in Figure 1.

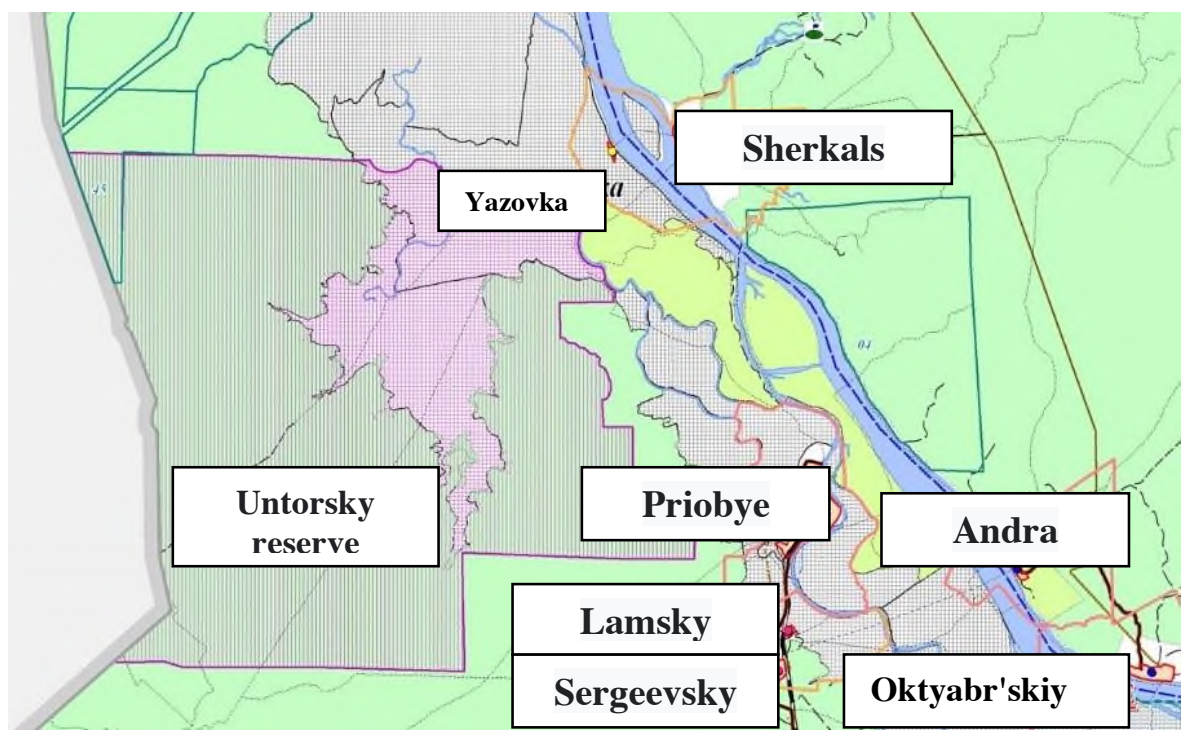

Fig. 1. Location of the reserve "Untorsky".

The Untorskiy reserve is located $8 \mathrm{~km}$ to the west of the urban settlement of Priob'e, which makes it possible to provide for a tourist infrastructure within the boundaries of the village. In the autumn-winter period from the urban-type settlement of Priob'e to the Untorsky reserve, transport links are carried out along the winter road. During the navigation period, river transport is used. The favorable location of the reserve is determined by the close location of the main waterway.

A dead-end single-track non-electrified railway enters the village. There is a railway station of the same name, from which long-distance communication is carried out, Priob'e Serov, Priob'e - Moscow, Priob'e - Ufa, Priob'e - Anapa (in summer), Priob'e Yekaterinburg.

There is also a helipad in the Ob region, but it is used only for communication with the island villages. 
Also, the urban settlement Priobye is located at a distance of $58 \mathrm{~km}$ from the urban district of Nyagan, transport links are carried out by road with a capital type of coverage.

As already noted, the urban district of Nyagan is a priority territory for the development of tourism, characterized by a sufficiently developed infrastructure - hotels, museums, a recreation center, ski resorts, cultural and sports facilities, public catering facilities

2. The state complex nature reserve of regional significance "Vogulka" was organized with the aim of preserving the population of elk and reindeer in places of winter storage, preserving and restoring their habitat, as well as for reproduction and protection of valuable commercial species of animals and birds. The protected area facility with an area of 64,747 hectares is located in the eastern part of the Berezovsky district, in the basin of the river. Northern Sosva, in the lower reaches of the Vogulka river basin. The location of the protected area facility is shown in Figure 2.

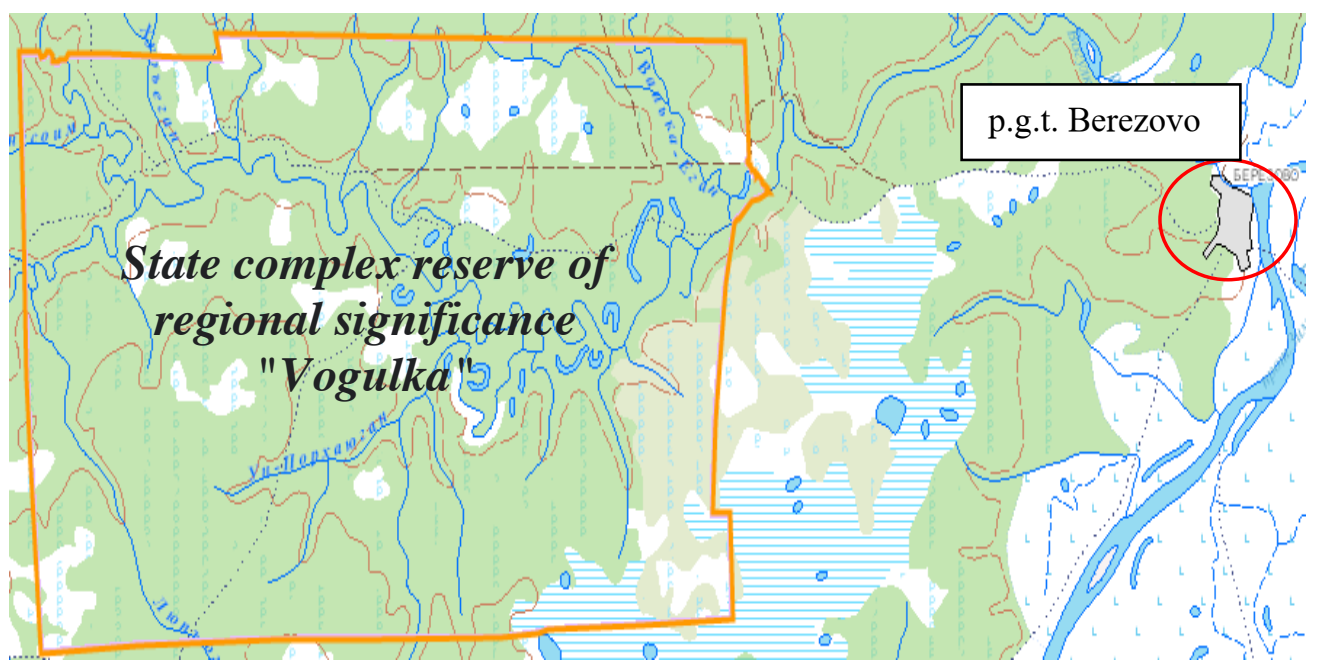

Fig. 2. Location of the Vogulka reserve.

The territory of the reserve is crossed by large and small rivers. The total length of the river network is $56 \mathrm{~km}$, the largest of which is the Vogulka river. This circumstance creates the preconditions for the organization of ecological tourism with elements of fishing.

The Vogulka reserve is located at a distance of just over $30 \mathrm{~km}$ from the urban-type settlement Berezovo, which is part of the urban settlement of Berezovo. Also next to the reserve is the village of Tutleimgorodsky settlement of Berezovo, however, at present, no one lives in the village (Figure 3).

Transport links between the village. Berezovo and the Vogulka reserve are carried out along the winter road, during the navigation period - by river transport.

Distance from the urban district of Nyagan to the town. Berezovo is more than $800 \mathrm{~km}$ long, with most of the areas without hard surface there are also areas where ferry travel is possible.

Thus, when organizing ecological tourism on the territory of the "Vogulka" reserve, the town may become a place for organizing and developing tourist infrastructure. Berezovo, because it has all the necessary conditions: close location to the protected area, constant transport links, a network of social, leisure, public places within the boundaries of the village, a rich fund of objects of historical and cultural heritage.

On the territory of the reserve, it is possible to develop ecological tourism with elements of fishing and hunting, because the permitted types of activities include amateur fishing (fishing rod and spinning rod) in specially designated places with observance of the limits 
and terms, hunting in order to regulate the number of hunting resources, subject to agreement with the institution that manages the protected area.

3. State natural biological reserve of regional significance "Berezovsky" with a total area of 43320 hectares was created in order to preserve, restore and reproduce hunting resources, as well as rare and endangered species of flora and fauna, preserve their habitat, migration routes, nesting sites, including protection of moose calving areas, fish spawning, as well as maintaining the overall ecological balance.

The reserve is located in the floodplain of the $\mathrm{Ob}$ river, its northern border runs along the Chukhlai-Nyurik channel, the western one - along the Malaya Ob river, and the southeast - along the Chukhlai channel from the lower mouth to the confluence with the Malaya Chukhlaika channel.

The protected area is also located on the territory of the Berezovsky district in the northeastern part of the municipality. One of the advantages of the reserve is the close distance from the village. Berezovo, which is $28 \mathrm{~km}$. Also near the reserve (less than $5 \mathrm{~km}$ ) is the village of Ustrem, which is part of the urban settlement of Berezovo. The settlement of Ustrem is home to 59 people, of which $76 \%$ are indigenous peoples of the North.

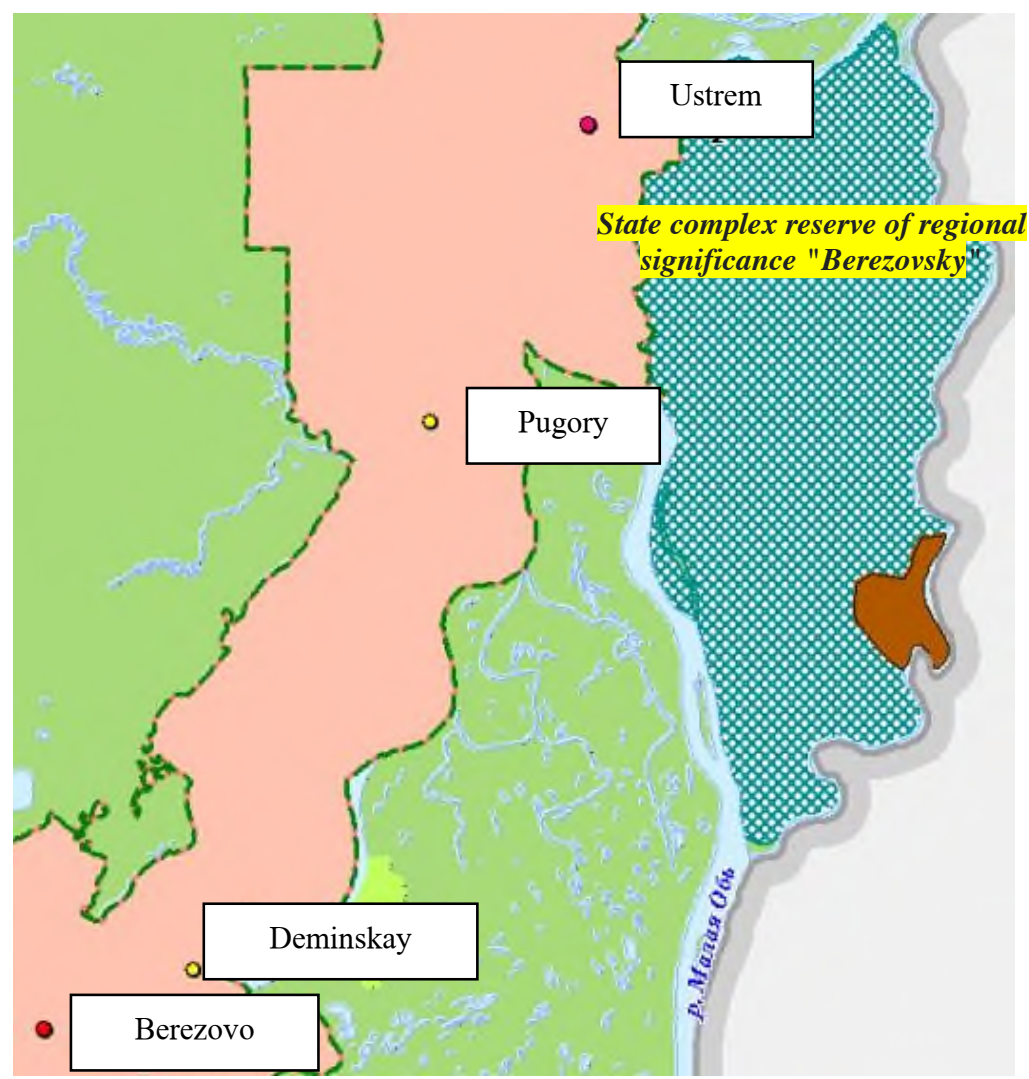

Fig. 3. Layout of the state complex reserve of regional significance "Berezovsky".

Accommodation of the population is possible on the territory of Ustrem, which will allow you to get acquainted with the culture, way of life, way of life of the indigenous peoples. Therefore, it is possible to organize ethnographic tours with elements of fishing on the territory of the reserve. The legal regime of the Berezovsky reserve provides for recreational and sport fishing (with a fishing rod and spinning rod) in specially designated areas. 


\section{Results and discussion}

We will determine the cost of ecological exploitation in the territories of the selected protected areas (table 2)

Table 2. The cost of ecological exploitation in the territories of the selected protected areas.

\begin{tabular}{|l|l|c|}
\hline \multicolumn{1}{|c|}{ Name of SPNA } & \multicolumn{1}{|c|}{$\begin{array}{c}\text { Orientation of } \\
\text { ecotourism }\end{array}$} & $\begin{array}{c}\text { Calculation of the cost of } \\
\text { ecological exploitation }\end{array}$ \\
\hline $\begin{array}{l}\text { State natural biological reserve } \\
\text { of regional significance } \\
\text { "Berezovsky" }\end{array}$ & $\begin{array}{l}\text { Hunting, gathering } \\
\text { wild plants }\end{array}$ & $1500+375+1800 * 12=23475$ \\
\hline $\begin{array}{l}\text { State complex reserve of } \\
\text { regional significance "Vogulka" }\end{array}$ & Hunting Fishing & $1500+375+1750 * 10+450 * 2=20275$ \\
\hline $\begin{array}{l}\text { State natural complex reserve of } \\
\text { regional significance "Untorsky" }\end{array}$ & $\begin{array}{l}\text { Hunting, gathering } \\
\text { wild plants }\end{array}$ & $1500+375+1800 * 20=37875$ \\
\hline
\end{tabular}

We will calculate the rent for the PAs involved in the recreational area. (Table 3)

Table 3. Rent for protected areas in the recreational area of the Berezovsky district.

\begin{tabular}{|l|c|c|c|}
\hline \multirow{2}{*}{$\begin{array}{c}\text { Resource and tourism } \\
\text { rent }\end{array}$} & \multicolumn{3}{|c|}{ Discount rate. rub / person } \\
\cline { 2 - 4 } & $\mathbf{2 \%}$ & $\mathbf{6 \%}$ & $\mathbf{1 0 \%}$ \\
\hline $\begin{array}{l}\text { State natural biological } \\
\text { reserve of regional } \\
\text { significance } \\
\text { "Berezovsky" }\end{array}$ & 469.5 & 1408.5 & 2347.5 \\
\hline $\begin{array}{l}\text { State complex reserve } \\
\text { of regional significance } \\
\text { "Vogulka" }\end{array}$ & 405.5 & 1216.5 & 2027.5 \\
\hline $\begin{array}{l}\text { State natural complex } \\
\text { reserve of regional } \\
\text { significance } \\
\text { "Untorsky" }\end{array}$ & 757.5 & 2272.5 & 3787.5 \\
\hline
\end{tabular}

We will forecast revenues to the revenue side of budgets of different levels from the implementation of environmental exploitation at protected areas in the Berezovsky municipal district, using the method of average values based on absolute growth schemes. simple and compound interest schemes. (Table 4)

Table 4. Forecast of receipts to the revenue side of budgets of different levels from the implementation of environmental exploitation at the facilities of protected areas in the Berezovsky municipal district.

\begin{tabular}{|l|c|c|c|}
\hline \multirow{2}{*}{ Territory name } & \multicolumn{3}{|c|}{ Budget income from tourist rent in protected } \\
\cline { 2 - 4 } & $\mathbf{2 0 2 0}$ & $\mathbf{2 0 2 1}$ & $\mathbf{2 0 2 2}$ \\
\hline $\begin{array}{l}\text { State natural biological reserve of } \\
\text { regional significance "Berezovsky" }\end{array}$ & 781084 & 793196 & 805441 \\
\hline $\begin{array}{l}\text { State complex reserve of regional } \\
\text { significance "Vogulka" }\end{array}$ & 674978 & 684837 & 694804 \\
\hline $\begin{array}{l}\text { State natural complex reserve of } \\
\text { regional significance "Untorsky" }\end{array}$ & 1263644 & 1277564 & 1291638 \\
\hline
\end{tabular}

Thus, after analyzing the potential of the protected areas located near the main waterways of the Khanty-Mansi Autonomous Okrug-Yugra, as well as the conditions for the development of tourism infrastructure in nearby settlements, it is possible to draw up the following tourist route, which is based on the protected areas. 


\section{Conclusion}

Having analyzed the potential capabilities of protected areas located near the main waterways of the Khanty-Mansi Autonomous Okrug-Yugra, as well as the conditions for the development of tourism infrastructure in nearby settlements, it is possible to draw up the following tourist route. the basis of which are protected areas (Figure 4).

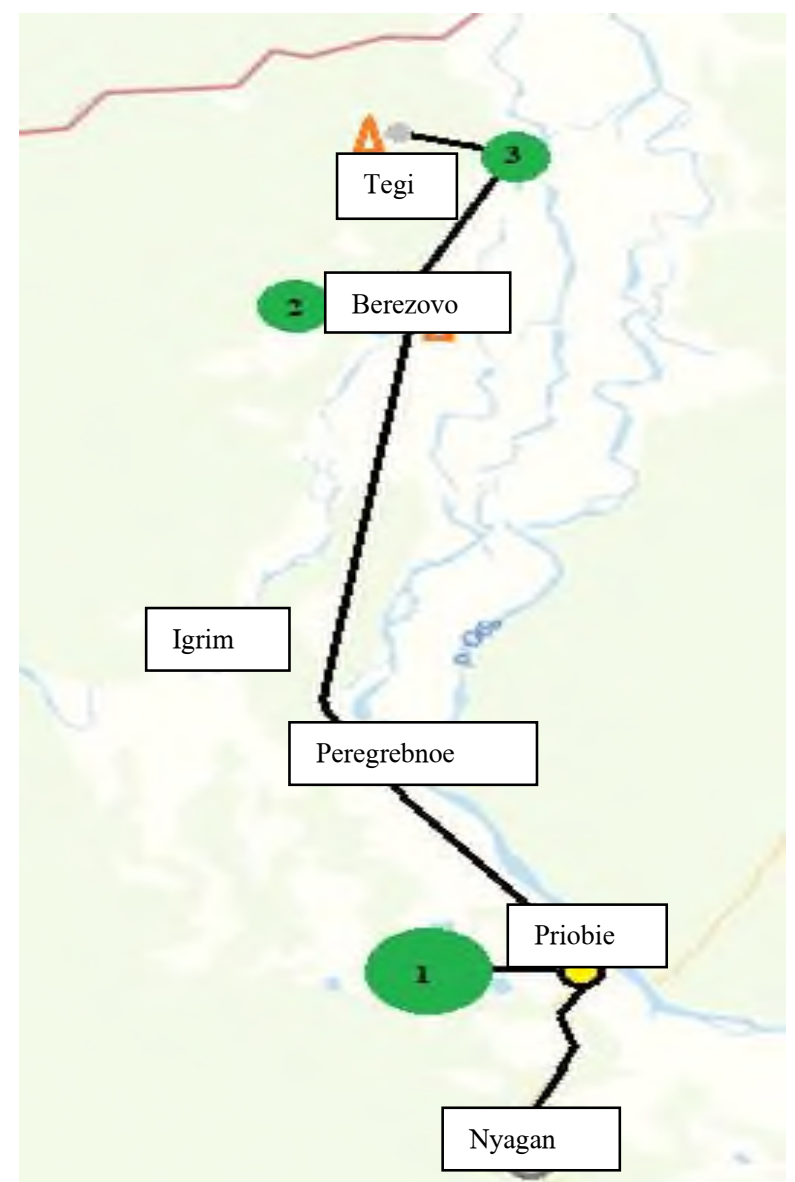

Fig. 4. Tourist route through the protected areas of the Khanty-Mansi Autonomous Okrug-Yugra.

1 State natural complex reserve of regional significance "Untorsky" (Oktyabrsky district)

2 State complex reserve of regional significance "Vogulka" (Berezovsky district)

3 State Natural Biological Reserve of Regional Significance "Berezovsky" (Berezovsky District)

O

town. Priobie, town. Berezovo

$\triangle$ Historical and cultural objects 
Currently. achieving sustainable development is impossible without significant investment attraction. In Khanty-Mansi Autonomous Okrug-Yugra, a favorable investment climate is developing, there is an increase in investment activity, which is due to rich hydrocarbon resources, a high standard of living and employment of the population (human potential), a gradual improvement in business conditions, a wide investment portfolio, an emerging infrastructure for supporting investors, rich natural potential. availability of free land resources.

Considering the specialization of the district, based on the extraction of hydrocarbon resources. as well as the problems associated with the diversification of the economy (the district has a significant investment potential for its development. which can be used both in the basic sector of the regional economy and is aimed at enhancing economic diversification. infrastructure development), the region faces the task of developing investment activities in other areas, therefore. promising investment objects and sites have been identified in the territorial planning scheme.

Territorial planning for the placement of investment objects was carried out on the basis of an analysis of cluster structures.

The development priorities of the tourist and recreational cluster are aimed at creating competitive regional tourist products and promoting them to the Russian and international markets; development of the infrastructure of the tourism industry in the Autonomous Okrug, taking into account the provision of environmental safety, protection of biological and landscape diversity. conservation and rational use of natural heritage; development of a system of advanced training, retraining and training of personnel for tourism enterprises of the Autonomous Okrug, as well as increasing the efficiency of the system of their regulation and self-regulation.

The inclusion of protected areas in the composition of investment sites for building up the tourist and recreational cluster will make it possible to develop ecological tourism as a priority area of domestic and inbound tourism in the Khanty-Mansi Autonomous OkrugYugra. It is assumed that the creation of investment objects related to the development of ecological tourism will have budgetary (growth of additional revenues to the budget of the Khanty-Mansi Autonomous Okrug-Yugra, municipalities, authorized organizations that manage PAs) and social effects (creation of new jobs. including for indigenous small peoples).

\section{References}

1. V.V. Yurak, Theoretical and methodological approach to assessing the social value of natural resources. abstract of the dissertation ... candidate of economic sciences on special 08.00.05 (Yekaterinburg. 2017)

2. I.V. Demyanova, Tourist rent in the system of economic relations of the region. abstract of the dissertation ... candidate of economic sciences on special 08.00.01 (Cheboksary, 2009)

3. G.V. Zhigunova, Modern Research of Social Problems 7(51) (2015)

4. I.M. Yakovenko, Recreational nature management: methodology and research methods (Tavria, Simferopol, 2003)

5. Oslo Manual: Guidelines for Collecting and Interpreting Innovation Data (OECD. Eurostat, Paris, 2005) 